\title{
Spatial distribution and budget for submarine groundwater discharge in Eckernförde Bay (Western Baltic Sea)
}

\author{
Michael Schlüter ${ }^{1}$ and Eberhard J. Sauter \\ Alfred-Wegener-Institut, Am Handelshafen, D-27515 Bremerhaven, Germany
}

Claus E. Andersen and Henning Dahlgaard

Risø National Laboratory, Frederiksborgvej 399, P.O. Box 49, DK-4000 Roskilde, Denmark

\section{Paul R. Dando}

School of Ocean Sciences, University of Wales-Bangor, Isle of Anglesey LL59 5AB, Great Britain

\begin{abstract}
Submarine groundwater discharge (SGD) from subseafloor aquifers, through muddy sediments, was studied in Eckernförde Bay (western Baltic Sea). The fluid discharge was clearly traced by ${ }^{222} \mathrm{Rn}$ enrichment in the water column and by the chloride profiles in pore water. At several sites, a considerable decrease in chloride, to levels less than $10 \%$ of bottom-water concentrations, was observed within the upper few centimeters of sediment. Studies at 196 sites revealed that $>22 \%$ of the seafloor of the bay area was affected by freshwater admixture and active fluid venting. A maximal discharge rate of $>9 \mathrm{~L} \mathrm{~m}^{-2} \mathrm{~d}^{-1}$ was computed by modeling pore water profiles. Based on pore water data, the freshwater flow from subseafloor aquifers to Eckernförde Bay was estimated to range from $4 \times 10^{6}$ to $57 \times 10^{6} \mathrm{~m}^{3} \mathrm{yr}^{-1}$. Therefore, $0.3-4.1 \%$ of the water volume of the bay is replaced each year. Owing to negligible surface runoff by rivers, SGD is a significant pathway within the hydrological cycle of this coastal zone. High-resolution bathymetric data and side-scan sonar surveys of pockmarks, depressions up to $300 \mathrm{~m}$ long, were obtained by using an autonomous underwater vehicle. Steep edges, with depths increasing by more than $2 \mathrm{~m}$ within $8-10 \mathrm{~m}$ in lateral directions, equivalent to slopes with an angle of as much as $11^{\circ}$, were observed. The formation of pockmarks within muddy sediments is suggested to be caused by the interaction between sediment fluidization and bottom currents. Fluid discharge from glacial coastal sediments covered by mud deposits is probably a widespread, but easily overlooked, pathway affecting the cycle of methane and dissolved constituents to coastal waters of the Baltic Sea.
\end{abstract}

For coastal areas, Sonrel (1868) reported the discharge of freshwater from submarine springs and speculated on their use and risks for sailors. Since then a few studies have considered the importance of fluid discharge from sediments for nutrient budgets of coastal environments, formation of offshore plankton blooms, hydrological cycles, or the release of trace elements and gases such as radon from the seafloor (Johannes 1980; Valiela et al. 1990; Moore 1996; Cable et al. 1997; Laroche et al. 1997). For the South Atlantic Bight, on the eastern coast of the United States, Moore (1996) deduced that the quantity of submarine groundwater discharge (SGD; here taken as fresh plus salt water) represented $40 \%$ of the river input into the study area. Although these figures probably overestimate the contribution of submarine seepage

\footnotetext{
${ }^{1}$ Corresponding author (mschlueter@awi-bremerhaven.de).

\section{Acknowledgments}

We thank the captains and crews of RVs Littorina, A. v. Humbold, and Alkor for their support during several cruises. We are grateful to W. Lemke and J. Harff from the Institute of Baltic Research (IOW, Warnemünde) for providing the vibro corer system. Jayne Wolf-Welling is gratefully acknowledged for improving the English text. We thank DeBeers Marines/Maridan for conducting the AUV dives. Application of GIS was supported by Dr. A. Schäfer. The paper benefited from the comments and suggestions of two anonymous reviewers. This research was funded as part of the EU shared cost project Sub-GATE (contract no. ENV4-CT97-0631).
}

in this area (Younger 1996), this study revealed the significance of this pathway for marine chemistry.

Reports concerning fluid discharge in coastal areas, e.g., off Italy, Greece, Crete, Japan, Israel, Lebanon, Florida, and the Baltic proper, underlined the worldwide occurrence of this transport pathway from land to the ocean (Kohout 1966; Zektser 1996; Schlüter 2002; Taniguchi et al. 2002). Considering the different regional settings, different modes of fluid flow from sediments can be distinguished: (1) focused flow along fractures in karst and rocky areas, (2) dispersed flow through soft sediments, and (3) recirculation of seawater through sediments. The compositions of fluids range from nearly pure freshwater, as is the case in karst areas, to the seepage of saline water, as reported for regions off Florida (Cable et al. 1997).

Techniques used to localize discharge sites and to determine flow rates include: visual observation by towed camera systems, direct measurements by different types of seep meters, pore water investigations and modeling, measurements of sediment temperature, as well as water column studies of trace elements and naturally occurring radionuclides such as ${ }^{222} \mathrm{Rn}$ and ${ }^{226} \mathrm{Ra}$ (Moore 1996; Albert et al. 1998; Burnett et al. 2001; Taniguchi et al. 2002). Nevertheless, in most cases, the origin and subseafloor pathways of fluids and their impact on pore water composition is not well understood.

In this study we examine submarine groundwater discharge (SGD) in Eckernförde Bay (western Baltic Sea). For 

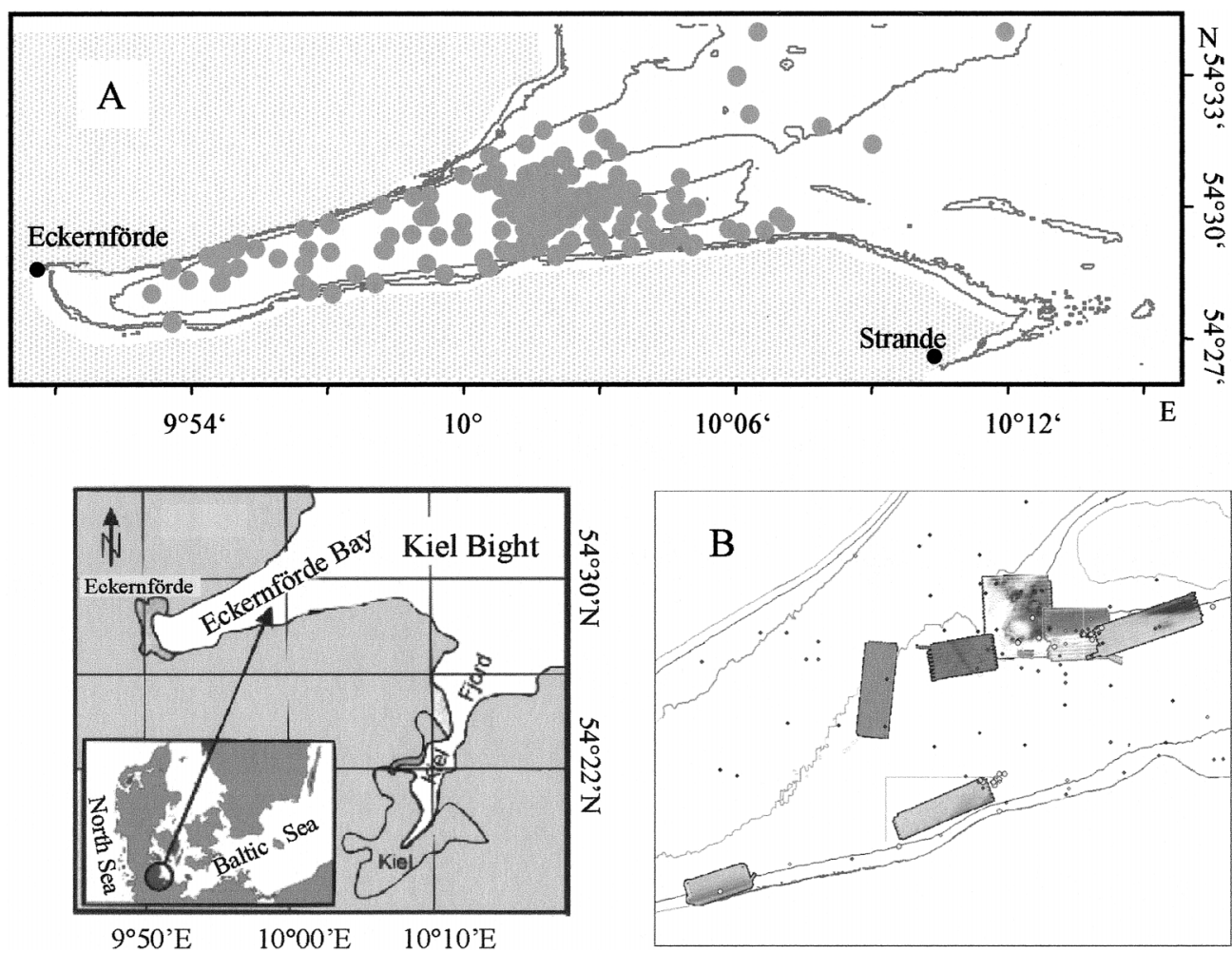

Fig. 1. (A) Study area of Eckernförde Bay and sampling sites of pore water studies. (B) Regions of side-scan sonar and high-resolution bathymetric surveys by autonomous underwater vehicle (AUV).

this region, Khandriche and Werner (1995), Albert et al. (1998), Bussmann et al. (1998), and Whiticar (2002) reported the effects of freshwater on pore water composition for a few pockmarks. Most previous studies focus on the effect of fluid flow on the sedimentary methane cycle, whereas the source of fluids, the spatial distribution of areas affected by freshwater, flow rates, and budgets for the discharge of fluids essentially remain unconsidered. We investigated these objectives by sediment and water column studies. A budget for freshwater discharge from a subseafloor aquifer and fluid flow through muddy sediments was calculated.

\section{Methods}

Sampling region and bathymetry-Eckernförde Bay, in the western Baltic Sea, has a length of approximately $19 \mathrm{~km}$ and a width of $9 \mathrm{~km}$ at its mouth (Fig. 1). The maximum water depths are 26 to $28 \mathrm{~m}$. In the eastern part of the bay, the basin is divided into two elongated troughs by the Mittelgrund, a moraine remnant, where water depths are less than $10 \mathrm{~m}$ (Jensen et al. 2002; Whiticar 2002). Pockmarks, elongated depressions approximately 1 to $3 \mathrm{~m}$ below adjacent seafloor levels, are located in water depths of 24 to 26 $\mathrm{m}$ around the Mittelgrund and along the southern shore.

Close to shore sandy sediments occur, whereas muddy deposits are found below water depths of 15 to $20 \mathrm{~m}$. The finegrained deposits are characterized by a median size of 15 to
$20 \mu \mathrm{m}$ and a low permeability in the range of $10^{-13}$ to $10^{-15}$ $\mathrm{m}^{-2}$.

High organic carbon contents of $>4 \%$ and occurrences of free gas are reported for the muddy sediments (Wever et al. 1998; Whiticar 2002). In this part of the Baltic Sea, the tides are a few centimeters at the most and changes in water level are generally wind driven.

Bathymetric data of the bay were received in digital form from the German Federal Maritime and Hydrographic Agency and augmented by bathymetric and sediment echo sounder surveys during several of our cruises. Bottom video observations were made using a 3-CCD (charge coupled device) digital video camera, which was towed at a fixed distance above the sediment on a sled. The field of view was approximately $0.5 \mathrm{~m}^{2}$.

Detailed information concerning the shape and spatial alignment of pockmark locations was obtained during dives with the autonomous underwater vehicle (AUV) M600 (A/ $\mathrm{S}$ Maridan). The M600 was equipped with a dual channel Klein 2000 side-scan sonar system $(100 \mathrm{kHz}$ and $500 \mathrm{kHz})$, which provides a horizontal resolution of $15 \mathrm{~cm}$, a GeoAcoustics Chirp for subbottom profiling, an (Sonar Research \& Development Ltd. (SRD) seabed visualization system, and a Seabird conductivity, temperature, depth (CTD) recorder. During eight dives (Fig. 1), each lasting as long as $7 \mathrm{~h}$, the M600 operated at 3 or $12 \mathrm{~m}$ above seafloor and surveyed regions formerly identified by pore water studies as discharge areas (including pockmarks and nonpockmark regions). 
Sediment and water sampling-Between 1998 and 2001, sediments were sampled at 196 sites throughout Eckernförde Bay (Fig. 1). Sediment cores of up to $120 \mathrm{~cm}$ in length were taken by a small gravity corer equipped with an acrylic liner (internal diameter $10 \mathrm{~cm}$ ). In general, clear bottom water overlying the sediment indicated the undisturbed sampling of sediment; this was supported by visual observation during video guided deployments of the corer. Immediately after recovery of the core, the sediment was moved by a piston to a reference line on the liner and sampled using 5-ml cut off syringes inserted into the sediment through predrilled holes in the side of the liner. This permitted the immediate sampling of sediments, with minimal loss of gases from the sediment after recovery of the core. Beginning at the sediment-water interface, samples were taken over the entire length of the core with $5 \mathrm{~cm}$ spacing. The holes were sealed tightly by tape before coring. A vibro corer system was used to obtain sediment cores of up to $6 \mathrm{~m}$ length from muddy and sandy deposits for pore water and sediment analysis. In this case the usual sample spacing was 25 to $40 \mathrm{~cm}$.

Subsamples of sediment were transferred into headspace vials and centrifuge cups, for methane and pore water analysis respectively. Five milliliters of alkali $(\mathrm{pH} \mathrm{12)}$ were pipetted into each headspace vial prior to the insertion of sediments, in order to stop bacterial activity. For pore water analysis, sediments were centrifuged, and the supernatant water was removed with a syringe and filtered through a cellulose acetate membrane filter of $0.2-\mu \mathrm{m}$ pore size. Sediment porosity was determined by weight difference after freeze drying of sediment samples.

Water column samples, for the analysis of methane and the naturally occurring isotopes ${ }^{222} \mathrm{Rn}$ and ${ }^{226} \mathrm{Ra}$, were collected with standard Niskin samplers. A horizontal water sampler was used to collect bottom water from less than 1 $\mathrm{m}$ above the seafloor. Water samples were transferred from the Niskin and horizontal samplers, without air contact, to 5- or 10-liter glass flasks, sealed tightly, and either analyzed on board or transferred immediately to the laboratory for analysis of ${ }^{222} \mathrm{Rn}$ and ${ }^{226} \mathrm{Ra}$.

Pore water analysis-Chloride concentrations were analyzed by Mohr-Knudsen titration (Grasshoff et al. 1983). Major elements, such as $\mathrm{Na}, \mathrm{K}, \mathrm{Mg}, \mathrm{Ca}$, were determined by ICP-AES (inductively coupled plasma atomic emission spectroscopy; Jobin-Yvon JY 170) for several pore water profiles. A standard headspace technique (Albert et al. 1998) was used to determine methane, which was measured on a Shimatzu gas chromatograph equipped with a flame ionization detector.

${ }^{222}$ Radon and ${ }^{226}$ Radium analysis-Fluid discharge from the seafloor can be estimated on the basis of the distribution of ${ }^{222}$ Radon (half-life $3.8 \mathrm{~d}$ ) and ${ }^{226}$ Radium (half-life 1,600 yr) in the water column (Moore 1996; Cable et al. 1997; Moore and Shaw 1998). ${ }^{222} \mathrm{Rn}$ is the product of ${ }^{226} \mathrm{Ra}$ decay in sediments and seawater. In seawater ${ }^{226} \mathrm{Ra}$ activity is generally low, whereas considerably higher levels of ${ }^{226} \mathrm{Ra}$ activity are found in the mineral matrix of soils and sediments. Groundwater samples and fluids escaping from the seafloor are therefore enriched in ${ }^{222} \mathrm{Rn}$ as compared to seawater.
${ }^{222} \mathrm{Rn}$ and ${ }^{226} \mathrm{Ra}$ are measured by extracting ${ }^{222} \mathrm{Rn}$ from water samples two times: as soon as possible after sampling, and again after 1 to 4 weeks, when sufficient ${ }^{222} \mathrm{Rn}$ has been produced as a result of ${ }^{226} \mathrm{Ra}$ decay in the tightly enclosed sample. The last measurement gives the ${ }^{226} \mathrm{Ra}$ concentration, and the difference between the two gives the excess ${ }^{222} \mathrm{Rn}$, radon in excess of the production by decay of ${ }^{226} \mathrm{Ra}$. Radon was measured by a modified emanation method (Mathieu et al. 1988) using a semiautomatic computer-controlled and monitored radon extraction system.

Calculation of discharge rates-In the marine environment chloride is an inert tracer, which undergoes no adsorption or reactions. Therefore, pore water profiles of $\mathrm{Cl}$ are controlled by transport processes such as advection, diffusion, and bioirrigation. For Eckernförde Bay the effects of bioirrigation and of the seasonal variation in bottom-water composition on pore water profiles were negligible below sediment depths $>10 \mathrm{~cm}$ (Schlüter et al. 2000). Therefore, $\mathrm{Cl}$ pore water profiles are controlled below this depth by advection and diffusion according to the equation

$$
v \frac{\partial \phi C}{\partial x}-\frac{D_{s} \partial^{2} \phi C}{\partial x^{2}}=0
$$

where $C$ is the concentration of $\mathrm{Cl}, \phi$ is porosity, $D_{s}$ is the molecular diffusion coefficient of $\mathrm{Cl}$ in the sediment, and $v$ is the advection rate. The $\mathrm{Cl}$ diffusion coefficient for sediment $\left(D_{s}\right)$ was calculated for average bottom-water temperature and salinity using the Stokes-Einstein Law and corrected for the effect of tortuosity according to Boudreau (1997). For the pore water profiles the diffusion coefficient is well constrained, and the advection rate is the remaining unknown in Eq. 1. Since seasonal fluctuations of bottomwater salinity are damped in sediment depths $>10 \mathrm{~cm}$ (Schlüter et al. 2000), a steady state was assumed for the modeling of $\mathrm{Cl}$ pore water profiles. By application of the finite volume approach and the Levenberg-Marquard method (Ferziger and Perić 1999), an optimized fit of calculated and measured pore water data was achieved and advection rates were derived for the pore water profiles.

Computation of spatial budgets-For the calculation of spatial distributions and budgets the geographic information system (GIS) ArcInfo was used. The Lamberth-Azimuthal projection was applied to convert geographic and bathymetric information to an equal area projection. Contour plots of $\mathrm{Cl}$ concentrations and calculated discharge rates were computed within the GIS environment.

\section{Results}

Our initial studies were on previously located pockmarks (Khandriche and Werner 1995; Wever et al. 1998; Whiticar 2002) near Mittelgrund (Fig. 1). Video camera observations showed that a fluid sediment-water interface was visible at the center of several of the pockmarks and that this interface appeared to have gentle undulations, suggesting that slow upward percolation was just sufficient to maintain a dense fluid-mud suspension. The sediment echo sounder and side- 
A

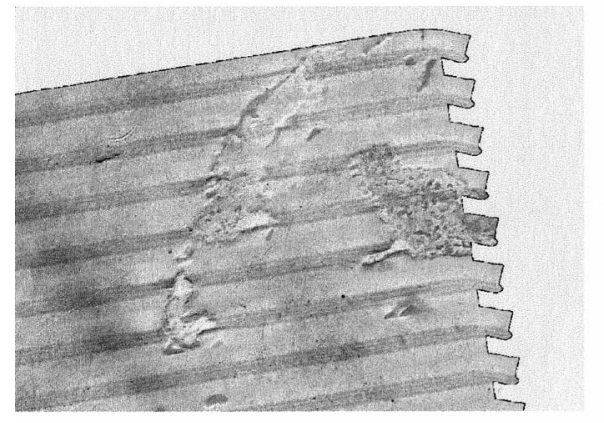

B

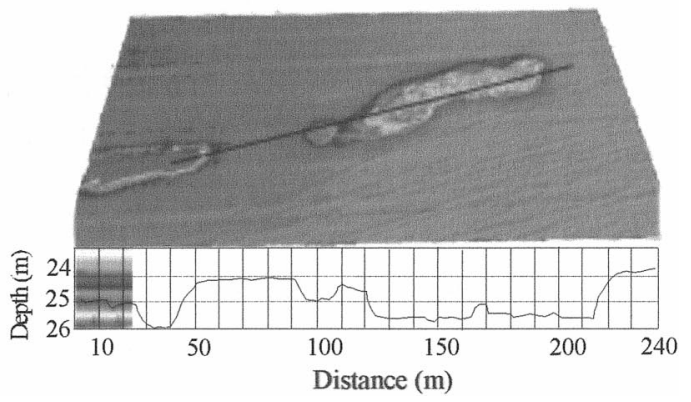

Fig. 2. (A) Side-scan sonar images of pockmark fields at water depths of 22 to $26 \mathrm{~m}$. The entire length of these structures is ca. $300 \mathrm{~m}$. (B) Bathymetric survey of a pockmark by AUV. The depth profile along the cross section (upper part) is indicated in the lower part.

scan sonar tracks surveyed by AUV revealed sediment depth structures and the occurrence of free gas. The side-scan sonar information showed that pockmarks are of nearly circular or elongated shape. The diameter of the circular type was usually $<30 \mathrm{~m}$. Pockmark fields of up to $300 \mathrm{~m}$ in length were observed by the side-scan sonar survey (Fig. 2A). High-resolution bathymetric data gathered during AUV dives revealed steep edges with depths increasing by more than $2 \mathrm{~m}$ within $8-10 \mathrm{~m}$ in lateral directions, equivalent to slopes with an angle of as much as $11^{\circ}$ (Fig. 2B).

Water column distributions of ${ }^{222} \mathrm{Rn}$ and ${ }^{226} \mathrm{Ra}$ and pore water analysis were applied to localize and quantify the dis-

\section{Radon-222 (mBq L-1)}
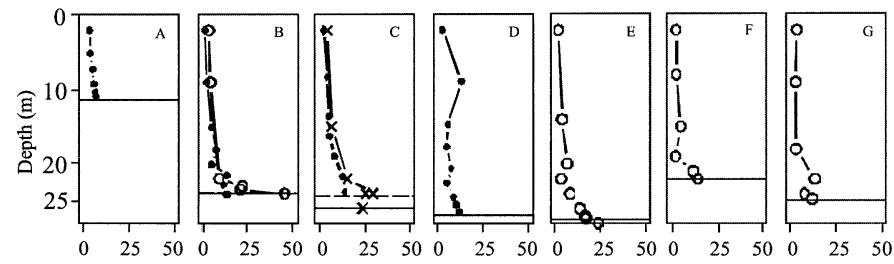

Radium-226 (mBq L-1)
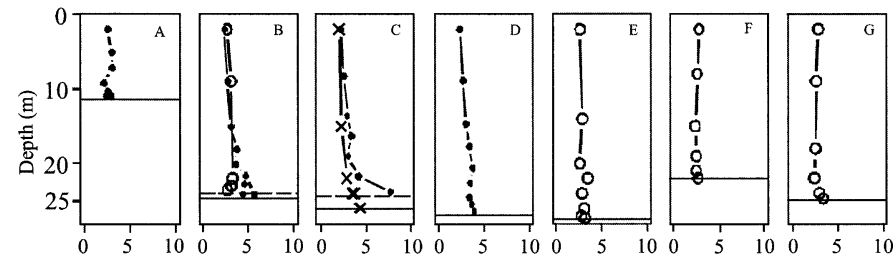

$$
\begin{gathered}
\times \text { Dec } 1998 \\
\text { - May } 2000 \\
\text { - Aug } 2000 \\
\text { - Sea floor }
\end{gathered}
$$

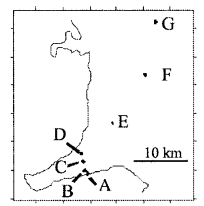

Fig. 3. Examples of water column profiles for ${ }^{222} \mathrm{Rn}$ and ${ }^{226} \mathrm{Ra}$ and the location of sampling sites. The inventory of excess ${ }^{222} \mathrm{Rn}$, calculated by the integration of the water column data, was in the range $20-200 \mathrm{~Bq} \mathrm{~m}^{-2}$. The mean excess of ${ }^{222} \mathrm{Rn}$ inventory for the 17 water column profiles was $80 \mathrm{~Bq} \mathrm{~m}^{-2}$. charge of fluids from the seafloor by different techniques. In general, an increase in ${ }^{222} \mathrm{Rn}$ activity was observed with water depth (Fig. 3). At sites between Mittelgrund and the southern shoreline, ${ }^{222} \mathrm{Rn}$ activities of more than $20 \mathrm{mBq} \mathrm{L}^{-1}$ were detected in bottom water (Fig. 4), suggesting a release of ${ }^{222} \mathrm{Rn}$ through the seepage of fluids. Average ${ }^{222} \mathrm{Rn}$ activities in surface and bottom water are 3.1 and $13.2 \mathrm{mBq} \mathrm{L}^{-1}$, respectively.

In contrast to radon, ${ }^{226} \mathrm{Ra}$ activities are nearly invariant with depth (Fig. 3). Average ${ }^{226} \mathrm{Ra}$ activities of 2.6 and 3.3 $\mathrm{mBq} \mathrm{L}{ }^{-1}$ were calculated respectively for surface and bottom waters. Comparing samples collected within the bay and the adjacent Kiel Bight shows similar ${ }^{226} \mathrm{Ra}$ activities (Fig. 4).

Excess ${ }^{222} \mathrm{Rn}$ activity (exceeding in situ production of radon by decay of ${ }^{226} \mathrm{Ra}$ ) was prevalent in seawater at virtually all locations. This means that there was a significant source of ${ }^{222} \mathrm{Rn}$ in addition to the activity caused by decay of ${ }^{226} \mathrm{Ra}$ in seawater. The inventory of excess ${ }^{222} \mathrm{Rn}$ was calculated by the integration of water column data. Inventories as great as $200 \mathrm{~Bq} \mathrm{~m}^{-2}$ and as low as $20 \mathrm{~Bq} \mathrm{~m}^{-2}$ were observed.

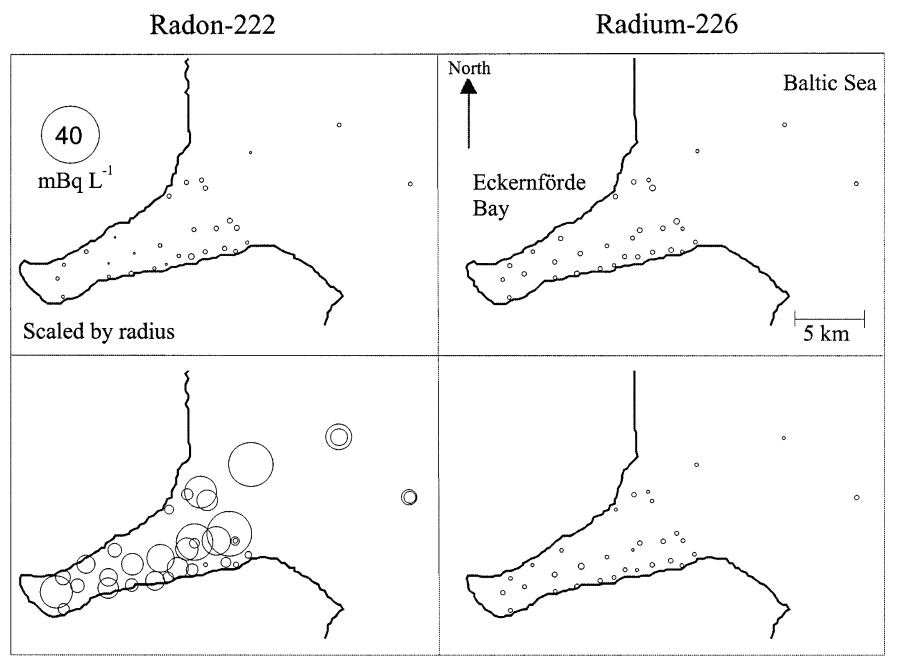

Fig. 4. Spatial distribution of ${ }^{222} \mathrm{Rn}$ and ${ }^{226} \mathrm{Ra}$ activities in surface water (upper) and bottom water (lower). The diameter of the circles is scaled as shown in the upper left panel. 

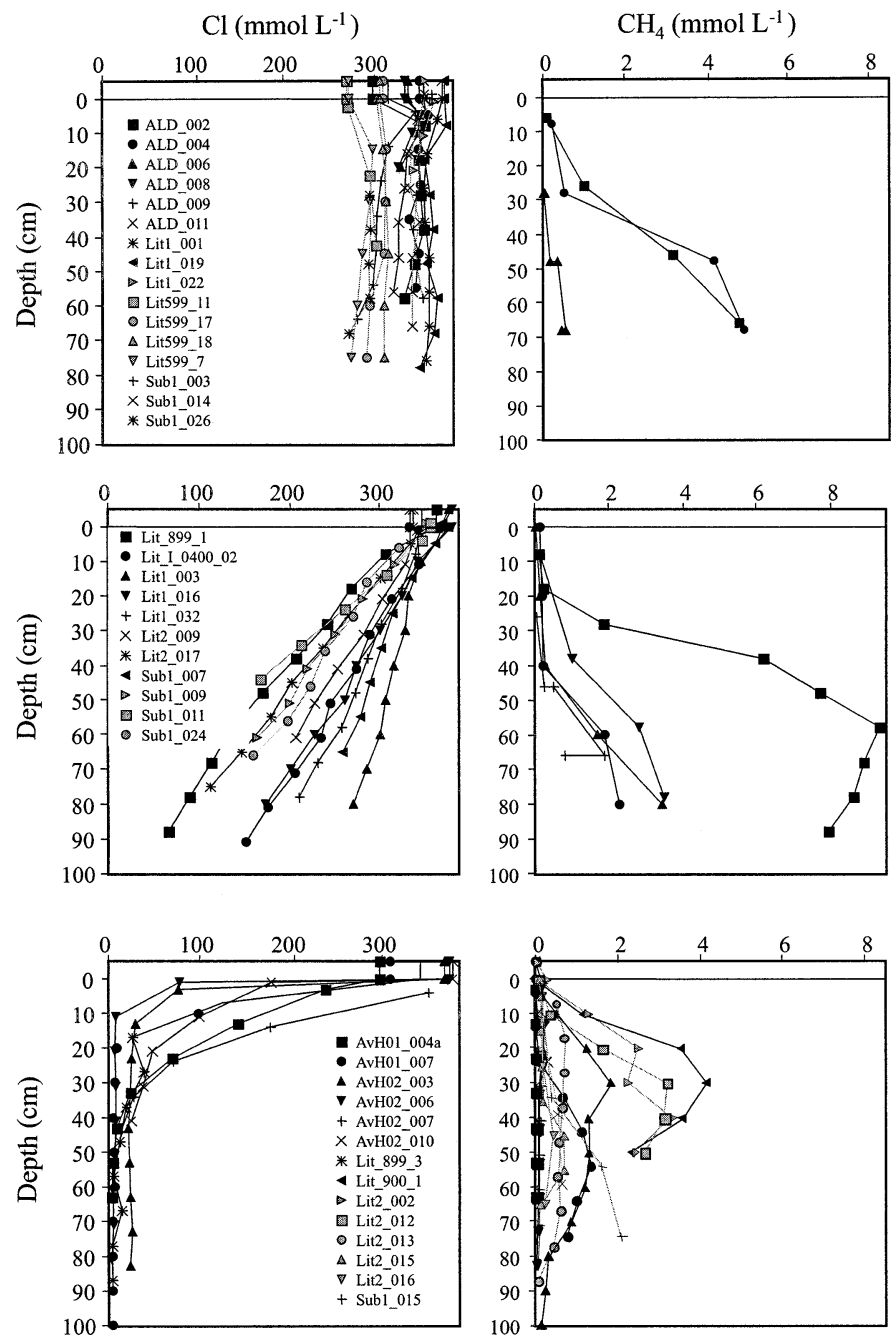

Fig. 5. Examples of pore water profiles for $\mathrm{Cl}$ (left panels) and methane (right panels). The profiles were grouped into three categories. Upper panels: constant concentrations with depth, indicating no affect of freshwater admixture. Middle panels: linearly decreasing profiles with depth, indicating admixture of freshwater by diffusion only. Lower panels: pore water profiles affected by fluid flow, causing a curvature in the pore water profile.

Most profiles have inventories of 40 to $130 \mathrm{~Bq} \mathrm{~m}^{-2}$. The mean excess ${ }^{222} \mathrm{Rn}$ inventory for the 17 water column profiles was $80 \mathrm{~Bq} \mathrm{~m}^{-2}$.

To consider ${ }^{222} \mathrm{Rn}$ production in sediments, emanation rates of ${ }^{222} \mathrm{Rn}$ have been measured using a slurry stripping technique (Martin and Banta 1992). The emanation rate gives the number of ${ }^{222} \mathrm{Rn}$ atoms available for advective or diffusive transport after escape from sediment particles. At 11 sites ${ }^{222} \mathrm{Rn}$ emanation in sediments was investigated. Minimal and maximal emanation rates of 3.1 to 12 atoms $\mathrm{s}^{-1}$ $\mathrm{kg}^{-1}$ dry mass, with a mean of $5.2( \pm 2.5)$, were measured.

Sediment sampling provided site-specific information concerning fluid discharge and its effect on benthic methane and nutrient cycles. Pore water profiles for $\mathrm{Cl}$ provided information about fluid transport in sediments (Fig. 5). The measured profiles could be grouped into three categories with respect to shape and asymptotic concentration at depth. Sites unaffected by freshwater were characterized by nearly constant $\mathrm{Cl}$ concentrations from the bottom water to sediment depths of more than $40 \mathrm{~cm}$ (Fig. 5A). The second category was characterized by a nearly linear decrease in $\mathrm{Cl}$ concentrations with depth (Fig. 5B). As supported by our pore water modeling, this suggests admixture by freshwater due to molecular diffusion with negligible fluid advection. The third category had low $\mathrm{Cl}$ concentrations at depth with profile curvature close to the sediment-water interface indicating active flow of freshwater (Fig. 5C).

It should be mentioned that the constant $\mathrm{Cl}$ profiles with depth (Fig. 5A) are not caused by injection of seawater into the sediment. This would affect other dissolved pore water components, such as silicic acid, which was not observed in our data. At these sites Si pore water profiles showed the typical curvature and increase of $\mathrm{Si}$ to an asymptotic value at depth. Furthermore, our time series study considering the annual variation of $\mathrm{Cl}$ in surface sediments (Schlüter et al. 2000) showed that constant $\mathrm{Cl}$ concentrations with depth were a result of molecular diffusion.

At several sites, the intense admixture of freshwater resulted in $\mathrm{Cl}$ concentrations of $<30 \mathrm{mmol} \mathrm{L}^{-1}(<10 \%$ of bottom-water concentration) at sediment depths of $10-20 \mathrm{~cm}$ (Fig. 5C). In addition to chloride concentrations, major ions, such as $\mathrm{K}, \mathrm{Mg}$, and $\mathrm{Na}$, were also affected by freshwater admixture.

The Levenberg-Marquardt method was applied to derive an optimal fit of calculated to measured data for modeling $\mathrm{Cl}$ pore water profiles to compute fluid flow through the sediment (Fig. 6). High flow rates of $>5 \mathrm{~L} \mathrm{~m}^{-2} \mathrm{~d}^{-1}$ were observed only at a few sites. The average flow rate was 0.54 $\mathrm{L} \mathrm{m}^{-2} \mathrm{~d}^{-1}$. For $\mathrm{Cl}$ profiles that had an essentially linear decrease with depth (Fig. 5B), modeling showed that molecular diffusion was the dominant transport process, whereas fluid advection was negligible.

Methane concentrations were measured in water column and sediment samples. In the water column, $\mathrm{CH}_{4}$ concentrations were generally between 13 and $700 \mathrm{nmol} \mathrm{L}^{-1}$. At some sites high concentrations (e.g., up to $1,900 \mathrm{nmol} \mathrm{L}^{-1} \mathrm{CH}_{4}$ ) were measured close to the seafloor (Fig. 7). This suggests the release of $\mathrm{CH}_{4}$ associated with seepage of fluids from the seafloor.

High $\mathrm{CH}_{4}$ concentrations were observed at several sites in the organic rich sediments of the bay (Fig. 5). Pore water concentrations of methane are often close to $\mathrm{CH}_{4}$ saturation. Free gas was detected in sediments (Wever et al. 1998; Whiticar 2002), and ebullition of gas bubbles from the seafloor was occasionally observed by our towed video systems. Nevertheless, low $\mathrm{CH}_{4}$ concentration was measured at some sites, although high organic carbon contents were favoring formation of $\mathrm{CH}_{4}$ (Figs. 5, 8). Flushing of $\mathrm{CH}_{4}$ from sediments by fluid flow was suggested as a mechanism causing low concentrations (Albert et al. 1998; Bussmann et al. 1998; Whiticar 2002). Even though some of our pore water profiles support this assumption, fluid flow of freshwater from below did not always cause low $\mathrm{CH}_{4}$ concentrations (Fig. 5C). For example, at pockmark sites, very high as well as low concentrations of $\mathrm{Cl}$ and $\mathrm{CH}_{4}$ were observed in close proximity, suggesting strong horizontal and lateral gradients (Figs. 8, 9). 

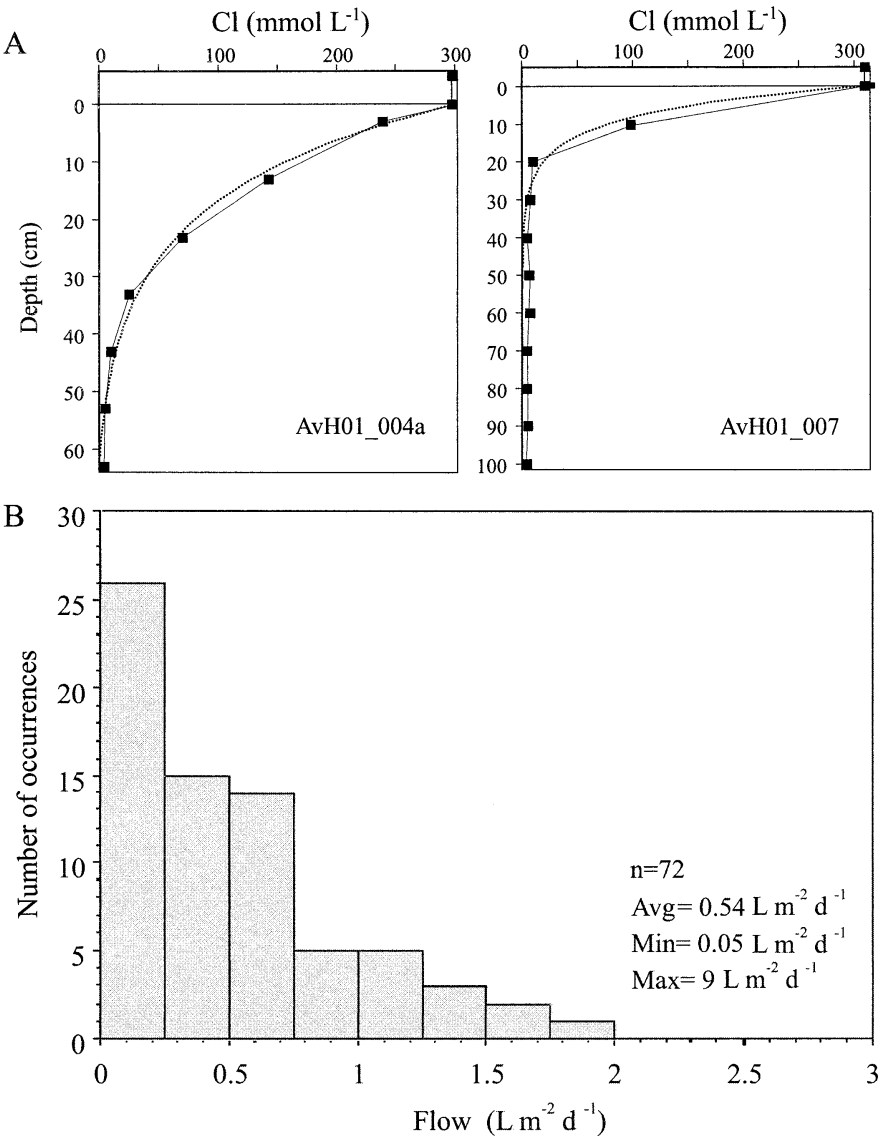

Fig. 6. (A) Examples of the computation of discharge rates by modeling pore water data. The dotted line represents the modeled profile. (B) Histogram summarizing calculated flow rates derived for 72 sites affected by fluid flow. An average flow of $0.54 \mathrm{~L} \mathrm{~m}^{-2}$ $\mathrm{d}^{-1}$ was calculated.

\section{Discussion}

Budget of fluid discharge based on ${ }^{222} \mathrm{Rn}$ inventories${ }^{226} \mathrm{Ra}$ and ${ }^{222} \mathrm{Rn}$ activities can be used to derive budgets for the release of fluids from the seafloor (e.g., Moore 1996; Cable et al. 1997; Corbett et al. 2000). Groundwater sampled from the subseafloor aquifer, located $>5 \mathrm{~m}$ below seafloor, had a ${ }^{222} \mathrm{Rn}$ activity of 5,000 to $10,000 \mathrm{mBq} \mathrm{L}{ }^{-1}$, approximately three orders of magnitude larger than the average seawater level. The groundwater was also enriched in ${ }^{226} \mathrm{Ra}$ ( 8 to $116 \mathrm{mBq} \mathrm{L}^{-1}$ ), and locations subject to submarine groundwater discharge should therefore also have an increased level of ${ }^{226} \mathrm{Ra}$. However, since the groundwater concentration of ${ }^{226} \mathrm{Ra}$ was only approximately threefold higher than the seawater concentration, submarine groundwater discharge will have less impact on the ${ }^{226} \mathrm{Ra}$ seawater concentration than will a release of ${ }^{222} \mathrm{Rn}$. This supports the different spatial patterns of ${ }^{222} \mathrm{Rn}$ and ${ }^{226} \mathrm{Ra}$ activities observed within the water column of the bay (Figs. 3, 4).

The inventory and spatial pattern of ${ }^{222} \mathrm{Rn}$ in Eckernförde Bay seems to be a suitable tracer of fluid discharge, whereas ${ }^{226} \mathrm{Ra}$ showed no obvious trends (Figs. 3, 4). ${ }^{226} \mathrm{Ra}$ does not appear to be an indicator of submarine groundwater dis-

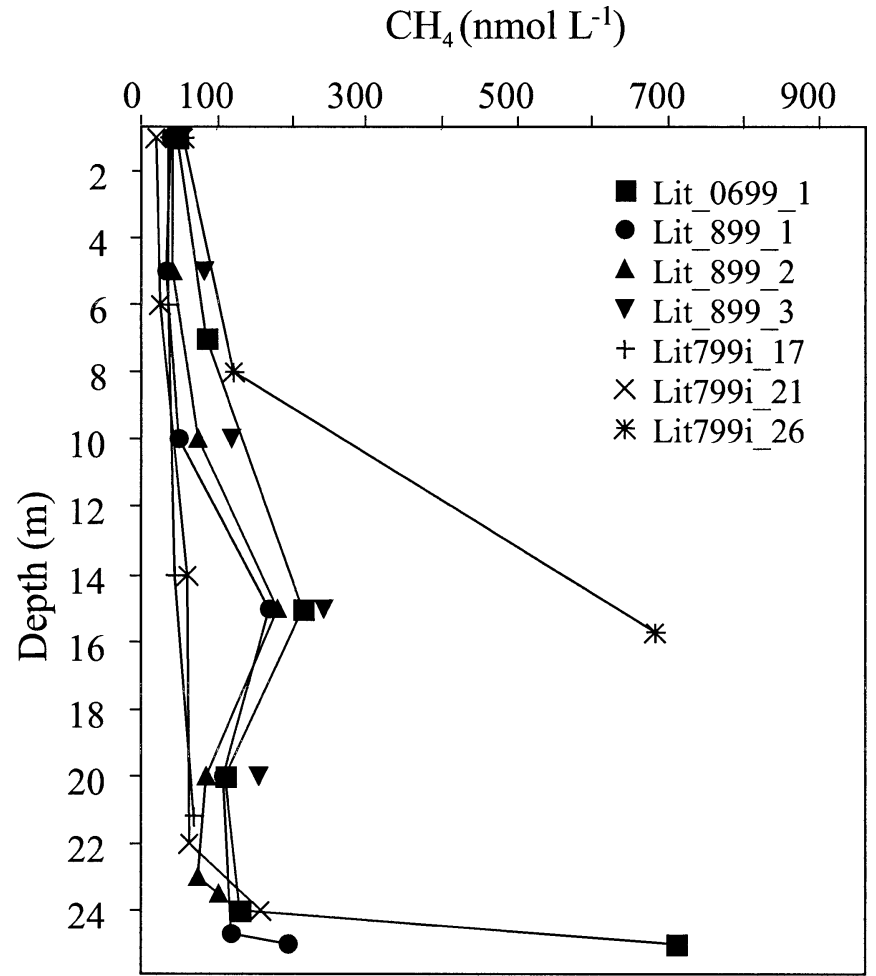

Fig. 7. Profiles of $\mathrm{CH}_{4}$ in the water column at sites where enhanced concentrations were observed close to the seafloor. A horizontal water sampler was used to collect bottom water at a distance of less than $1 \mathrm{~m}$ above the seafloor.

charge in Eckernförde Bay, in contrast to other coastal regions (Moore 1996; Burnett et al. 2001). Compared to that of ${ }^{222} \mathrm{Rn}\left(t_{1 / 2}=3.8 \mathrm{~d}\right)$, the longer half-life of ${ }^{226} \mathrm{Ra}\left(t_{1 / 2}=\right.$ $1,600 \mathrm{yr}$ ) exceeds the residence time of the water in Eckernförde Bay, which is on a scale of a few weeks. Therefore, vertical and lateral mixing of ${ }^{226} \mathrm{Ra}$ within the bay and subsequent exchange with Baltic Sea water would cause a low activity of ${ }^{226} \mathrm{Ra}$. In contrast, the mixing of water masses is on a similar time scale to the half-life of ${ }^{222} \mathrm{Rn}$. ${ }^{222} \mathrm{Rn}$ decay during the advection of water masses from sites with en-
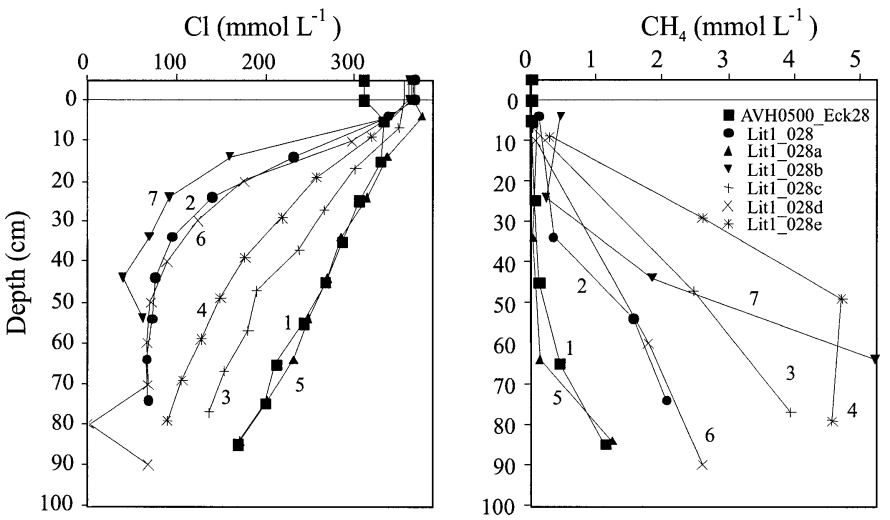

Fig. 8. Pore water profiles of $\mathrm{Cl}$ and $\mathrm{CH}_{4}$ in a transect across a pockmark site near the Mittelgrund. Numbers 1 to 7 refer to the contour plot shown in Fig. 9. 


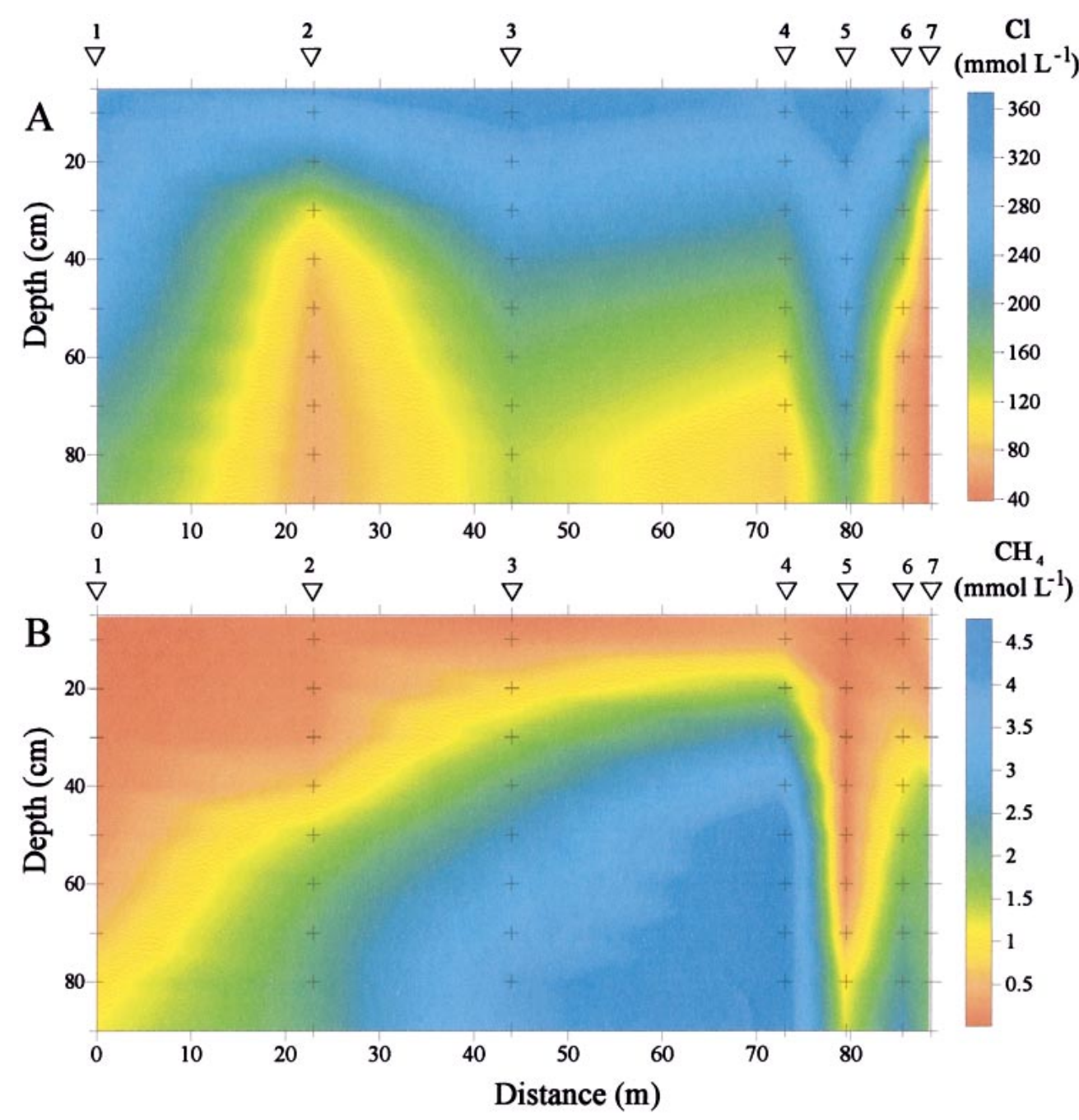

Fig. 9. Contour plots computed for (A) $\mathrm{Cl}$ and (B) $\mathrm{CH}_{4}$ pore water profiles across a pockmark site near Mittelgrund (Fig. 8). The length of the transect was $95 \mathrm{~m}$. The upper $90 \mathrm{~cm}$ of the sediment are considered. Positions of sampling sites are indicated by open triangles.

hanced activities causes a small export of ${ }^{222} \mathrm{Rn}$ to the upper water column and other areas of the bay. High ${ }^{222} \mathrm{Rn}$ levels close to the seafloor indicate that ${ }^{222} \mathrm{Rn}$ excess is supplied from the sediments.

To estimate the amount of submarine groundwater discharge into Eckernförde Bay we considered the following model: groundwater with a ${ }^{222} \mathrm{Rn}$ concentration $c\left(\mathrm{~Bq} \mathrm{~m}^{-3}\right)$ flows into the bay at a steady rate $Q\left(\mathrm{~m}^{3} \mathrm{~s}^{-1}\right)$, and ${ }^{222} \mathrm{Rn}$ is removed from the water column by radioactive decay. Ignoring other sources and sinks, the following balance is obtained: $\lambda A I=c Q$, where $\lambda$ is the decay constant of ${ }^{222} \mathrm{Rn}$ (66.163 $\left.\mathrm{yr}^{-1}\right), A$ is the area of the bay $\left(\sim 70 \mathrm{~km}^{2}\right)$, and $I$ is the mean excess ${ }^{222} \mathrm{Rn}$ inventory ( $80 \mathrm{~Bq} \mathrm{~m}^{-2}$, Fig. 3) computed from water column profiles. If we set $c$ equal to the highest level measured in the well water $\left(10,000 \mathrm{mBq} \mathrm{L}{ }^{-1}\right.$; Sauter et al. 2001), we obtain a steady discharge rate $(Q)$ of approximately $37 \times 10^{6} \mathrm{~m}^{3} \mathrm{yr}^{-1}$ for the bay. By using the maximum dissolved Rn concentration, derived for the subseafloor groundwater, we should obtain a minimum estimate of the discharge rate.
In the former approach we assumed that the ${ }^{222} \mathrm{Rn}$ activity of subseafloor groundwater, located in depths $>5 \mathrm{~m}$ below seafloor (bsf), was identical to ${ }^{222} \mathrm{Rn}$ activity escaping to bottom waters. This assumption required a direct pathway for fluids connecting the subseafloor aquifer with the bottom water, as in karstic ducts. Within the muddy, low permeable sediments such direct pathways were not observed by our video and AUV surveys. If the sediment through which the groundwater flows is without a ${ }^{222} \mathrm{Rn}$ source, the entire ${ }^{222} \mathrm{Rn}$ signal would be lost after transport through $>5 \mathrm{~m}$ of sediment, considering the computed discharge rates (Fig. 6). The sediment had a relatively large emanation rate of ${ }^{222} \mathrm{Rn}$, and pore water fluids reached equilibrium with emanation rates in the sediment. This enabled the calculation of the pore water ${ }^{222} \mathrm{Rn}$ concentration $c_{\mathrm{pw}}$ as $c_{\mathrm{pw}}=\rho_{g} E(1-\phi) / \phi$, where $\phi$ is porosity, $\rho_{g}$ is grain density, and $E$ is the emanation rate. With an average derived emanation rate of 5.2 atoms $\mathrm{s}^{-1}$ $\mathrm{kg}^{-1}$, a grain density of $2 \times 10^{3} \mathrm{~kg} \mathrm{~m}^{3}$, and a porosity of $90 \%$, we estimated a pore water concentration of approximately $1.1 \mathrm{~Bq} \mathrm{~L}^{-1}$. As an alternative approach, the pore wa- 
ter concentration allowed the assessment of the overall maximum rate of ${ }^{222} \mathrm{Rn}$ transferred, by discharge of fluids and diffusion, from sediment to water column as $337 \times 10^{6} \mathrm{~m}^{3}$ $\mathrm{yr}^{-1}$. This value and our previous estimate, based on the assumption that groundwater flows into the bay with a ${ }^{222} \mathrm{Rn}$ activity identical to that measured in the wells, suggested that the discharge rates were in the range of $37 \times 10^{6}$ to $337 \times 10^{6} \mathrm{~m}^{3} \mathrm{yr}^{-1}$.

Freshwater admixture, spatial distribution, and budget of fluid seepage-A detailed view of the spatial distribution of fluid flow through sediments and freshwater admixture was provided by the 196 pore water profiles collected within the bay (Fig. 1A). Sites affected by freshwater were identified by nearly linear pore water profiles of $\mathrm{Cl}$ as well as by profiles with a considerable curvature (Fig. 5B,C). Whereas the latter result from active fluid flow, linear pore water profiles indicate a freshwater reservoir at depth. Compared to transport by diffusion, advection rates were negligible in the case of linear profiles. This suggests (1) the presence of impermeable layers such as clays between the freshwater reservoir and the sediment surface and/or (2) insignificant low hydraulic gradients causing a standstill of fluid flow.

For the first case, the depth of the freshwater reservoir below seafloor can be estimated by linear extrapolation of pore water profiles. According to Fig. 5B, the minimal and maximal depths of this reservoir would be $\sim 40 \mathrm{~cm}$ and $\sim 360 \mathrm{~cm}$ bsf. For more than $90 \%$ of linear pore water profiles the reservoir was estimated to be at a depth of less than $140 \mathrm{~cm}$ bsf. Since distinct impermeable layers were not observed within the mud sequence, linear $\mathrm{Cl}$ profiles would suggest the occurrence of unconfined freshwater reservoirs. These reservoirs should be hydraulically isolated from the subseafloor artesian aquifer below, thus causing no fluid flow. This does not seem to be a likely assumption, since no freshwater reservoirs underlain by saltwater were detected during our sampling surveys (Fig. 1A).

We suggest that the linear $\mathrm{Cl}$ profiles are caused by low hydraulic gradients causing a temporary standstill of fluid flow from the subseafloor aquifer. We assume a temporary standstill, since otherwise the linear profiles (Fig. 5B) should have similar slopes with depths of subseafloor aquifers $(>4$ $\mathrm{m}$ bsf) as the lower boundary. They represent the transition from profiles with curvature close to the sediment-water interface to linear profiles with diffusion of $\mathrm{Cl}$ from bottom water into the sediment. This assumption, instead of one based on isolated freshwater reservoirs, is also supported by the frequently observed close proximity of linear profiles and those showing considerable curvature. At a pockmark site near Mittelgrund, for example, both profile types were less than a few meters apart (Figs. 8, 9).

We suggest that the interplay between variations in the flow field (e.g., due to changes in hydraulic head caused by the water table in the bay) and kinetics of $\mathrm{CH}_{4}$ production and consumption are causing this spatial variability observed at pockmark sites. This hypothesis is also supported by model results of Hinkelmann et al. (2002). Consequently, a twodimensional or three-dimensional consideration of transport and reaction processes at pockmarks is required for a detailed interpretation of fluid flow and methane inventories.
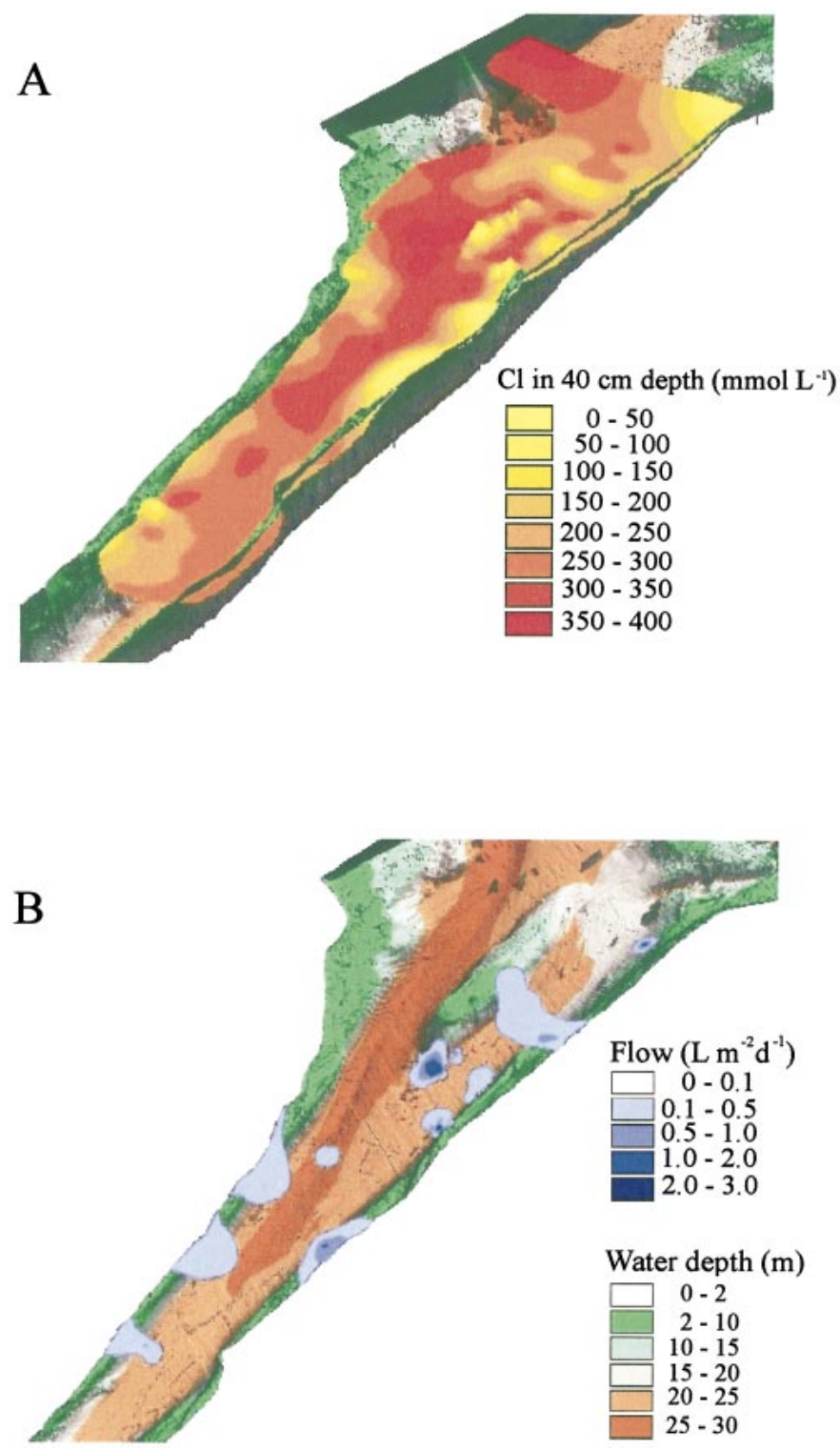

Fig. 10. Contour plots of $\mathrm{Cl}$ concentrations in (A) $40 \mathrm{~cm}$ bsf and (B) fluid flow draped on top of the three-dimensional bathymetric map showing the relationship of freshwater admixture to water depth. The spatial distribution of $\mathrm{Cl}$ concentrations in panel A indicates the intensive admixture of freshwater for the southern part of the bay and the Mittelgrund area in the center of Eckernförde Bay. The spatial distribution in panel B of fluid seepage from the seafloor and flow rates was derived by pore water modeling.

For example, within a pockmark, the horizontal diffusion of methane from sites of higher production to regions depleted by flushing may replenish $\mathrm{CH}_{4}$ inventories in regions of intensive fluid flow (Hinkelmann et al. 2002). Therefore, fluid flow may not always cause a flushing of methane from muddy sediments.

In order to derive the regional pattern of sediments affected by the admixture of fresh water, $\mathrm{Cl}$ pore water concentrations were examined at a depth of $40 \mathrm{~cm}$ below seafloor (Fig. 10). We chose this reference horizon, since seasonal variations in bottom-water salinity at this depth 
have a negligible effect on $\mathrm{Cl}$ concentrations (Schlüter et al. 2000), so that the $\mathrm{Cl}$ concentration at $40 \mathrm{~cm}$ reflects the admixture of freshwater caused by diffusion or advection from below. Particularly along the southern shore, the spatial distribution of $\mathrm{Cl}$ concentrations at $40 \mathrm{~cm}$ bsf shows an intense impact of freshwater on pore water composition (Fig. 10). In several regions, pore water $\mathrm{Cl}$ concentrations were less than $10 \%$ to $20 \%$ of average bottom-water composition. Another region of low $\mathrm{Cl}$ concentration was identified in the center of the Eckernförde Bay along the southern edge of the Mittelgrund. Along the northern shore of the bay only a few regions were affected by fluid flow. Here, the occurrence of freshwater was essentially limited to regions in the inner and outer portions of the bay. In total, an area of $\sim 17 \mathrm{~km}^{2}$, which is $\sim 22 \%$ of the entire area of Eckernförde Bay, was affected by the admixture of groundwater from depth.

Whereas the spatial distribution of $\mathrm{Cl}$ concentrations at 40 $\mathrm{cm}$ bsf indicates the admixture of freshwater and saline bottom water within the sediment, the computation of areas affected by active fluid flow requires the consideration of calculated discharge rates (Figs. 6, 10). These discharge rates were computed assuming steady state conditions, although some $\mathrm{Cl}$ profiles showing a considerable linear decrease with depth (Fig. 5B) suggest temporary standstill of fluid flow and non-steady state conditions for some sites. Nevertheless, we consider the derived discharge rates as a first approximation describing the fluid flow of freshwater from the subbottom aquifer through muddy sediments.

Regions of intense fluid flow were observed along the southern shore of Eckernförde Bay and at Mittelgrund (Fig. 10). In several of these regions, side-scan sonar and bathymetric surveys showed the occurrence of pockmarks (Fig. 2). Fluid flow was also observed in areas in which no distinct morphological features such as pockmarks were observed at the seafloor. For the entire bay, with an area of $\sim 70 \mathrm{~km}^{2}$ and a volume of $\sim 1,400 \times 10^{6} \mathrm{~m}^{3}$, a discharge from the seafloor of $4 \times 10^{6}$ to $57 \times 10^{6} \mathrm{~m}^{3} \mathrm{yr}^{-1}$ was estimated. This volume of freshwater, vented through the seafloor annually, is therefore equivalent to $0.3-4.1 \%$ of the entire water volume of the bay. Although an intense sampling program was conducted (Fig. 1), we assume that the calculated discharge represents a very conservative estimate. Particularly within pockmarks, where fluid discharge is high, coring of sediments is difficult due to the very soft, semiliquid consistency of these deposits.

The annual fluid discharge deduced from pore water profiles $\left(4 \times 10^{6}\right.$ to $\left.57 \times 10^{6} \mathrm{~m}^{3} \mathrm{yr}^{-1}\right)$ lies within a similar range to the budget derived by the ${ }^{222} \mathrm{Rn}$ inventory of the water column $\left(37 \times 10^{6}\right.$ to $\left.337 \times 10^{6} \mathrm{~m}^{3} \mathrm{yr}^{-1}\right)$. Measurements of short-lived tracers such as ${ }^{223} \mathrm{Ra}$ and ${ }^{224} \mathrm{Ra}$ (half-life of 11.4 and $3.6 \mathrm{~d}$, respectively) might be required to improve the estimates based on radio-nuclides. Despite a potential overestimation of the ${ }^{222} \mathrm{Rn}$ inventory, caused by molecular diffusion from sediments unaffected by fluid flow, and undersampling of pore water profiles at sites of intense fluid flow and sediment fluidization, the overall similarity supports the reliability of discharge rates derived by pore water and water column studies. Owing to negligible surface river runoff rates into Eckernförde Bay, the submarine groundwater discharge is a significant pathway within the hydrological cycle of this coastal zone.

Submarine groundwater discharge has a considerable influence on the ${ }^{222} \mathrm{Rn}$ inventory of the water column and on the pore water composition of sediments in Eckernförde Bay. Pore water studies revealed that an area of $\sim 22 \%$ of the seafloor was affected by freshwater admixture caused by diffusive transport and/or fluid advection from a subseafloor aquifer, located at $>4 \mathrm{~m}$ bsf (Sauter et al. 2001). Advection rates of $>9 \mathrm{~L} \mathrm{~m}^{-2} \mathrm{~d}^{-1}$, with an average discharge of $0.54 \mathrm{~L} \mathrm{~m}^{-2}$ $\mathrm{d}^{-1}$, were derived by pore water modeling. These flow rates resulted from freshwater seepage from the subseafloor aquifer. Even during the AUV surveys, operating a few meters above seafloor, no seepage of pure freshwater or regions of low bottom-water salinity were detected by the continuous CTD records. This might be due to the admixture of freshwater and more saline pore water during fluid flow through muddy sediments. For our study area, the term submarine groundwater discharge describes the release of freshwater from the subseafloor aquifer, whereas modified pore water seeps from the sediment-water interface into the bottom water.

Discharges similar to those observed in Eckernförde Bay were reported for the Great South Bay off New York (Bokuniewicz 1980), coastal bays of New England (Valiela et al. 1990), Chesapeake Bay (Gallagher et al. 1996; Reay et al. 1996), and the northeastern coastal Gulf of Mexico (Rasmussen 1998). At least in some cases, these discharge rates also included the effect of recirculated seawater (Taniguchi et al. 2002), whereas the pore water composition is essentially unaffected by recirculation of seawater for muddy sediments of Eckernförde Bay.

Within the entire bay $\left(\sim 70 \mathrm{~km}^{2}\right)$, pore water modeling suggests a submarine fluid discharge of $4 \times 10^{6}$ to $57 \times 10^{6} \mathrm{~m}^{3}$ $\mathrm{yr}^{-1}$. The budget based on ${ }^{222} \mathrm{Rn}$ inventories of the water column gave an estimate of $37 \times 10^{6} \mathrm{~m}^{3} \mathrm{yr}^{-1}$ to $337 \times 10^{6} \mathrm{~m}^{3}$ $\mathrm{yr}^{-1}$. Although both attempts rely on differing techniques and constraints (e.g., the pore water profiles assumed steady state conditions and the ${ }^{222} \mathrm{Rn}$ estimates ignore molecular diffusion of radon from the seafloor) the budgets were within similar ranges. As a conservative estimate for fluid flow from the seafloor we suggest $4 \times 10^{6}$ to $57 \times 10^{6} \mathrm{~m}^{3} \mathrm{yr}^{-1}$, equivalent to $0.3-4.1 \%$ of the entire water volume of the bay.

The highest discharge rates were derived for pockmark sites, suggesting a coupling of pockmark formation and fluid flow. One mechanism for the formation of circular depressions in lake and river deposits is the fluidization of sediments caused by fluid flow from below, forming "sand boils" (Guhman and Pederson 1992). For muddy sediments in Eckernförde Bay, the interaction of fluid flow and bottom currents is suggested to be a mechanism for the formation and preservation of pockmarks. Fluid flow through sediments decreases the shear strength of the sediment matrix, and periodic strong bottom currents, including episodic storm surges, cause preferential erosion of these areas when compared to adjacent seafloor, which in turn preserves sharp 
edges and the considerable slope within the pockmarks observed by AUV and towed video systems.

Fluid flow was also obvious for sites at which no distinct morphological features were observed at the seafloor. The considerable small-scale variability of $\mathrm{Cl}$ and $\mathrm{CH}_{4}$ at pockmarks (Fig. 9) suggests an intensive interaction of transport processes with methane production and consumption kinetics. Changes in the forcing factors of fluid flow such as hydraulic head (here, e.g., the water level height in Eckernförde Bay) cause lower/higher flow velocities and different flow paths. This permits diffusion of methane from sites of higher content to regions formerly depleted due to fluid flow, underlining the need for improved sampling techniques to record small-scale variation at discharge sites.

Ecological aspects associated with fluid discharge, although not at the center of this study, seem to be likely. The large area affected by freshwater ( $\sim 22 \%$ of the entire bay) might affect benthic habitats, and nutrient release from sediments to the water column will be enhanced due to advective transport. The geological setting of glacial coastal sediments covered by organic rich mud deposits observed for Eckernförde Bay may be representative for other coastal zones of the Baltic Sea where submarine groundwater discharge from subseafloor aquifers could be of similar relevance.

\section{References}

Albert, D. B., C. S. Martens, And M. J. Alperin. 1998. Biogeochemical processes controlling methane in gassy coastal sediments Part 2: Groundwater flow control of acoustic turbidity in Eckernförde Bay Sediments. Cont. Shelf Res. 18: 17711793.

BoKUnIEwICZ, H. 1980. Groundwater seepage into Great South Bay, New York. Estuar. Coast. Mar. Sci. 10: 437-444.

BoudREAU, B. P. 1997. Diagenetic models and their implementation. Springer. Heidelberg.

Burnett, W. C., M. Taniguchi, and J. Oberdorfer. 2001. Measurement and significance of the direct discharge of groundwater into the coastal zone. J. Sea Res. 46: 109-116.

Bussmann, I., P. R. Dando, S. J. Niven, And E. Suess. 1998. Groundwater seepage in the marine environment: Role for mass flux and bacterial activity. Cont. Shelf Res. 18: 17951806.

Cable, J. E., W. C. Burnett, and J. P. Chanton. 1997. Magnitudes and variations of groundwater seepage into shallow waters of the Gulf of Mexico. Biogeochemistry 38: 189-205.

Corbett, D. R., K. Dillon, W. C. Burnett, and J. Chanton. 2000. Estimating the groundwater contribution into Florida Bay via natural tracers, ${ }^{222} \mathrm{Rn}$ and $\mathrm{CH}_{4}$. Limnol. Oceanogr. 45: 1546-1557.

Ferziger, J. H., AND M. PerIĆ. 1999. Computational methods for fluid dynamics. Springer.

Gallagher, D. L., A. M. Dietrich, W. G. Reay, M. C. Hayes, AND G. M. Simmons, JR. 1996. Ground water discharge of agricultural pesticides and nutrients to estuarine surface water. Ground Water Monit. Remediation (Winter): 118-129.

Grasshoff, K., M. Ehrhardt, And K. Kremling. 1983. Methods of seawater analysis. Verlag Chemie.

Guhman, A. I., AND D. T. Pederson. 1992. Boiling sand springs,
Dismal River, Nebraska: Agents for formation of vertical cylindrical structures and geomorphic change. Geology 20: 8-10.

Hinkelmann, R., H. Sheta, H. Class, E. J. Sauter, R. Helmig, AND M. SCHLÜTER. 2002. Numerical simulation of freshwater, salt water and methane interaction processes in a coastal aquifer, p. 263-281. In J. Chadman, A. Cunningham, R. E. Ewing, P. Ortoleva, and M. F. Wheeler [eds.], Resource recovery, confinement, and remediation of environmental hazards. Springer.

Jensen, J.-B., A. KuiJPers, O. Bennike, T. Laier, And F. Werner. 2002. New geological aspects for freshwater seepage and formation in Eckernförde Bay, western Baltic. Cont. Shelf Res. 22: 2159-2173.

JOHANNES, R. E. 1980. The ecological significance of the submarine discharge of groundwater. Mar. Ecol. Prog. Ser. 3: 365-373.

KHANDRICHE, A., AND F. WERNER. 1995. Freshwater induced pockmarks in a bay of Eckernfoerde, Western Baltic, pp. 155-163. In J. E. Mojski [ed.], Proceedings of the Third Marine Geological Conference "The Baltic," Prace Panst. Inst. Geol.

KoHout, F. A. 1966. Submarine springs: A neglected phenomenon of coastal hydrology. Hydrology 26: 391-413.

Laroche, J., R. Nuzzi, R. Waters, K. Wyman, P. Falkowski, AND D. WALlaCE. 1997. Brown tide blooms in Long Island's coastal waters linked to interannual variability in groundwater flow. Global Change Biol. 3: 397-410.

Martin, W. R., AND G. BANTA. 1992. The measurement of sediment irrigation rates: A comparison of the $\mathrm{Br}$ tracer and ${ }^{222} \mathrm{Rn} /$ ${ }^{226} \mathrm{Ra}$ disequilibrium techniques. J. Mar. Res. 50: 125-154.

Mathieu, G. G., P. E. Biscaye, and R. A. Lupton. 1988. System for the measurement of Rn-222 at low levels in natural waters. Health Phys. 55: 929-943.

Moore, W. S. 1996. Large groundwater inputs to coastal waters revealed by ${ }^{226} \mathrm{Ra}$ enrichments. Nature 380: $612-614$.

, AND T. J. SHAw. 1998. Chemical signals from submarine fluid advection onto the continental shelf. J. Geophys. Res. 103: 21543-21552.

RASMUSSEN, L. L. 1998. Groundwater flow, tidal mixing and haline convection in coastal sediment. M.S. thesis, Florida State Univ.

Reay, W. G., D. L. Gallagher, And G. M. Simmons JR. 1992. Groundwater discharge and its impact on surface water quality in a Chesapeake Bay inlet. Water Resour. Bul. 28: 1121-1134.

Sauter, E. J., T. Laier, C. E. Andersen, H. DahlgaArd, And M. SCHLÜTER. 2001. Sampling of sub-seafloor aquifers by a temporary well for CFC age dating and natural tracer investigations. J. Sea Res. 46: 177-185.

SCHLÜTER, M. 2002. Fluid flow in continental margin sediments, $p$. 205-217. In G. Wefer, D. Billett, D. Hebbeln, B. B. Jørgensen, M. Schlüter, and T. C. E. van Weering [eds.], Ocean margin systems. Springer.

, E. Sauter, H.-P. Hansen, And E. Suess. 2000. Seasonal variations of bioirrigation in coastal sediments: Modelling of field data. Geochim. Cosmochim. Acta 64: 821-834.

SonRel, L. 1868. Le Fond de la Mer. Librarie De L. Hachette.

Taniguchi, M., W. C. Burnett, J. E. Cable, and J. V. Turner. 2002. Investigation of submarine groundwater discharge. Hydrol. Proc. 16: 2115-2129.

Valiela, I., J. Costa, K. Foreman, J. M. Teal, B. Howes, And D. Aubrey. 1990. Transport of groundwater-borne nutrients from watersheds and their effects on coastal waters. Biogeochemistry 10: 177-197.

Wever, T. F., F. AbegG, H. M. Fiedler, G. Fechner, And I. H. STENDER. 1998. Shallow gas in the muddy sediments of Eckernförde Bay, Germany. Cont. Shelf Res. 18: 1715-1739. 
WhiticAR, M. 2002. Diagenetic relationships of methanogenesis, nutrients, acoustic turbidity, pockmarks and freshwater seepages Eckernförde Bay. Mar. Geol. 182: 29-53.

Younger, P. L. 1996. Submarine groundwater discharge. Nature 382: $121-122$.

ZeKTSER, I. S. 1996. Groundwater discharge into the seas and oceans: State of the art, p. 122-123. In R. W. Buddemeier [ed.], Groundwater discharge in the coastal zone. LOICZ/Russian Academy of Sciences: Texel.

Received: 27 November 2002 Accepted: 28 July 2003 Amended: 1 October 2003 